\title{
PEDPNTE

\section{6) Envelhescência: a chave de um envelhecimento ativo e significativo}

\begin{abstract}
Fernanda Lima Avena'; Fhernnanda Fernandes Góes'; Ligia Mara dos Santos Corrêa Moura'; Maria Liz Cunha de Oliveira²; Karla Helena Coelho Vilaça²
\end{abstract}

\section{Resumo}

Envelhecer com nova significância, quebrando paradigmas com ousadia, persistência e vencendo obstáculos. Não seria essa a chave para um novo envelhecimento ativo e saudável? O texto busca analisar o discurso sobre envelhecimento ativo a partir do documentário "Envelhescência", partindo da premissa que a velhice é uma construção social. Apesar da avançada idade, os idosos retratados no filme praticam surf, corrida, para-quedismo, Aikido, estudam, fazem tatuagens e desempenhando atividades associadas à juventude.

Palavras-chave: longevidade, atividade física, idoso, envelhecimento saudável.

\section{Aging-cence: the key to active and significant aging}

\section{Abstract}

Aging with new significance, breaking paradigms with boldness, persistence and overcoming obstacles. Would not that be the key to a healthy and active new aging? The text seeks to analyze the discourse on active aging from the documentary " Aging-cence", starting from the premise that old age is a social construction. Despite the advanced age, the elderly people portrayed in the film practice surfing, running, parachuting, Aikido, studying, getting tattoos and performing activities associated with youth.

Keywords: longevity, physical activity, elderly, healthy aging.

Mestrandas no Programa de Pós-Graduação em Gerontologia da Universidade Católica de Brasília. Endereço para correspondência: QS 07 Lote 01 - EPCT - 71966-700 - Águas Claras - Taguatinga - DF. Emails (na ordem em que aparecem): flima@ucb.br; nandagoesfisio@gmail.com; elmoura99@gmail.com;

2 Professores do Programa de Pós-Graduação em Gerontologia da Universidade Católica de Brasília. Emails (na ordem em que aparecem): lizcunhad@gmail.com; kavilaca@yahoo.com.br 